\title{
The cleric, the acolyte and the lay man determined, if necessary, as the ministers of Holy Communion
}

The minister of Holy Communion is the one whose task is allowed by liturgical legislation. There is a division on the ordinary ministers, they are the bishop, priest and deacon, and extraordinary ministers that are acolytes and lay men who are called to their service as a substitute for other ministers. The ordinary ministers can perform their service, unless they are not forbidden by the law as a result of imposed fines or bans. And, if there is a situation that the ordinary ministers cannot make the ministry, as disease, other service or too large number wishing to receive Holy Communion, the extraordinary minister can give Holy Communion. The extraordinary minister of Holy Communion is also the acolyte, what arise from the nature of his appointment to serve at the altar. If Holy Communion is provided on the way of Viaticum, the ministers are: parish priest, assistant priests, chaplain, and some superiors of religious institutes. In cases of necessity or with the consent of these ministers, this ministry can be made by other ordinary and extraordinary ministers.

Key words: minister of Holy Communion, acolyte, extraordinary minister, Viaticum, authorization.

The minister in the Catholic Church is the person who has the right to implement relevant functions in the community of believers. In the matter of giving Holy Communion, the minister is the one who 
distributes to the faithful the Body and the Blood of the Lord ${ }^{1}$. One should clearly distinguish between the ministers of the celebration of the Eucharist from the ministers of Holy Communion. The minister ${ }^{2}$, who can perform the Sacrament of the Eucharist, is only lawfully ordained priest ${ }^{3}$. However, according to CIC Canon 910, the one who distributes the Sacrament of the Eucharist can be not only a priest, but also the deacon or the lay man specially assigned for this. The extension of the range of people admitted to providing the Holy Communion, is determined and defined in the legislation, depending on the situation in which the Sacrament is given ${ }^{4}$.

There is a distinction among ministers of Holy Communion: the ordinary minister of Holy Communion and the extraordinary minister ${ }^{5}$. The ordinary minister is a bishop, a priest and a deacon. The extraordinary minister is an acolyte and a faithful who has been authorized in accordance with the law ${ }^{6}$.

A situation, which, in a special way, specifies the minister, is giving Holy Communion as Viaticum. The ministers are here, a parish priest, an assistant priests, a chaplain, and some of the superiors of religious institutes, but also in cases of necessity or the appropriate consent also the other ministers ${ }^{7}$.

$1 \quad$ Cf. G. O'Collins, E., Farrugia, Szafarz, [in:] Leksykon pojęć teologicznych $i$ kościelnych, G. O’Collins, E. Farrugia eds., Kraków 2002, p. 180.

2 In the Eucharist the term „minister" is used in a dual value, both for the priest of the Eucharist, and the minister of Holy Communion. Cf. G. Trevisan, L'Eucharystia, [in:] La funzione di santificare della Chiesa. A cura del Gruppo Italiano Docenti di Diritto Canonico, Milano 1995, p. 101.

3 Cf. Codex Iuris Canonici auctoritate Ioannis Pauli PP. II promulgatus, Vatican 1984, can. 900 § 1 (next CIC); Pius PP. XII, encyclica Mediator Dei, „Acta Apostolicae Sedis" 39 (1947) p. 553.

4 Cf. Congregatio de Cultu Divino et Disciplina Sacramentorum, instructio de quibusdam observandis et vitandis circa sanctissimam Eucharistiam Redemptionis sacramentum, 25.03.2004, no. 88, „Acta Apostolicae Sedis” 96 (2004), p. 549-601 (next RS).

5 Cf. E. Górecki, Najświętsza Eucharystia, [in:] Komentarz do Kodeksu Prawa Kanonicznego, W. Góralski, E. Górecki, J. Krukowski, J. Krzywda, P. Majer, B. W. Zubert eds., v. 3/2, book VI, Uświęcajace zadanie Kościoła, Lublin 2011, p. 95.

$6 \quad$ Cf. CIC, can. $910 \S 1$ i 2.

$7 \quad$ Cf. ibidem, can. $911 \S 1$ i 2. 


\section{Ordinary ministry of breaking the Holy Communion}

Breaking the Holy Communion by the ministers conforms to the love of God in the framework of the plan of security for the people of God. This context gives the meaning to consecrated minister in the community of believers ${ }^{8}$. In the tradition of the Church service of consecrated ministers is defined as "sacrament". The sacramental service of the ministers means giving by those who give what they themselves cannot do or give. Such giving involves the authorized by Christ, where the minister gets the sacred power of in persona Christi Capitis ${ }^{9}$. The minister is the reason for the grace of the Sacrament, which God has provided in his plan of security for receiving Holy Communion. The minister of Holy Communion was called to the ministry by the adoption of the sacrament of ordination. Ordinations are entrusted to give believers an opportunity to accept Christ, present in His Body and Blood $^{10}$.

\section{The ordinary ministers of Holy Communion}

The legislator of the Church in the Canon 910 CIC defines the ordinary ministers of Holy Communion (ministri ordinarii sacrea comunionis) in accordance with the instruction the Second Vatican Council, stating that: "The ordinary minister of holy community is a bishop, priest or a deacon"11. The dogmatic Conciliar Constitution about the Church Lumen Gentium, November 21, 1964, indicates that the bishop is the minister of the grace of the Supreme priesthood especially in the Eucharist that he brings, or cares about Its offering ${ }^{12}$.

8 Cf. Kongregacja do spraw duchowieństwa, Kapłan głosiciel stowa, szafarzsakramentówi przewodnik wspólnoty w drodze do trzeciego tysiąclecia chrześcijaństwa, 19.03.1999, Watykan 1999, p. 60-61.

Cf. Ioannis Pauli PP. II, Catechismus Catholicae Ecclesiae, Vatican 1992, no. 875 .

10 Cf. Szafarz sakramentów, [in:] Słownik podstawowych pojęć teologicznych, E. Ozorowski ed., Warszawa 2007, p. 278-279.

CIC 83, can. $910 \S 1$.

12 Cf. Sacrosanctum Concilium Oecumenicum Vaticanum II, Constitutio dogmatica de Ecclesia Lumen Gentium, 21.12.1964, no. 26, „Acta Apostolicae Sedis” 57 (1965) p. 5-71 (next LG). Being the minister in relation to the Eucharist, which the bishop himself does not give, but only cares about Its sacrifice, should be understood as the realization of authority of controlling Its correct celebration. The bishop performs this task with every legitimate celebration of the Eucharist by the priest. Cf. Missale Romanum ex decreto Sacrosancti Oecumenici Concilii Vaticani II instauratum auctoritate Pauli PP. VI promulgatum, editio typical 
Priests are associates of bishops, who by the sacrament of the priesthood participate in the one Mediation of Jesus Christ. Through their work as a replacement (in persona) of Christ, they carry out their Holy mission mainly in the celebration of the Eucharist. They perform the Sacrament of the Eucharist after they have taken priest ordination. The authority they have to the Eucharist and tasks associated with Its achievement belongs to the essence of the priestly ministry ${ }^{13}$. Deacons are placed hands not for the priesthood but for the ministry that trusts them by the competent authority, including the service of the liturgy, where their tasks are, for example, the distribution of the Eucharist ${ }^{14}$. The deacon can never preside over the Eucharist, however, his task is to help in Its implementation. This occurs when deacon accomplishes tasks related to being the ordinary minister of the Word of God and the Eucharist. In this case, the participation in ministry of the Eucharist is expressed through the possibility of providing It to Its faithful ${ }^{15}$.

Active participation in ministry of Holy Communion for priests, that is, for bishops and presbyters, should offer the Eucharist, not only in the name of Christ, but in His replacement, so there is a possibility of distribution of the consecrated host from the authorities that they have taken from ordination that cause their identification with the Supreme and Eternal Priest. However, it is important to specify the right touch of Holy Figures and the distribution to the believers as the benefit arising directly from the connection with Christ by the sacrament of ordination in all three degrees ${ }^{16}$.

The change made by the instruction of the Second Vatican Council to the existing legal norms is, expressed in the dogmatic Constitution about the Church, the fact of inclusion deacons into the circle of ordinary ministers to give Holy Communion ${ }^{17}$. Among Canonists there was doubt in the interpretation of the note in Conciliar Constitution,

\footnotetext{
altera 27.03.1975, Typis Polyglottis Vaticanis 1975, Institutio Generalis, no. 59 (next IGMR).

13 Cf. LG no. 17, 26, 28.

14 Cf. ibidem 29.

15 Cf. J. Nowak, Trójstopniowość sakramentu święcen,,[in:] Kapłaństwo, K. Czulak, L. Balter, P. Góralczyk eds., Poznań 1988, p. 98.

16 Cf. Ioannes Paulus PP. II, epistula de Sacrosanctum Eucharistiae mysterio et cultu Dominicae Cenae, 24.02.1980, no. 11, „Acta Apostolicae Sedis” 72 (1980) p. 113-133.

17 Cf. LG 29; P. Hemperek, Najświętsza Eucharystia, [in:] Komentarz do Kodeksu Prawa Kanonicznego z 1983, P. Hemperek, W. Góralski, F. Przytuła, J. Bakalarz eds., v. 3, Lublin 1986, p. 118.
} 
if deacon can actually be classified as the ordinary ministers providing the Eucharist. There were documents confirming the ability of giving the Holy Communion by deacons, for example, the motu proprio of Pope Paul VI Sacrum diaconatus ordinem, June 18, $1967^{18}$. The permanent diaconate was constituted then. The document also mentioned the possibility of ministry by the deacons to: storing the Eucharist, providing It to other people and themselves, and carrying Viaticum ${ }^{19}$. Also, the permission of the deacon to the Eucharist determines the leadership of the Congregation of Rites Eucharisticum Mysterium, May 25,1967 , which states that the distribution of Holy Communion belongs to the priest of the Eucharist and to other priests or deacons ${ }^{20}$. However, the principle of recognition of deacons for the ordinary ministers appeared only in the explanation that was given by the Congregation of Sacraments and God's Devotion in $1976^{21}$, and today, it operates on the principle of the Code Law, from 1983, contained in can. $910 \S 1$. Recognition of deacon as the ordinary minister of Holy Communication changed significantly look at the ministry of the deacon. In this law, although it is impossible to take full advantage of deacon's help by the priest during the Eucharist, it is the only limitation in the understanding of the deacon as minister of Holy Communion. During breaking Holy Communion the deacon does not need any additional permission from the priest ${ }^{22}$.

The usual character of the service of ministers of Holy Communion is also expressed in that ministers do not need any special permission

18 See Paulus PP. VI, motu proprio Sacrum diaconatus ordinem, 18.06.1967, no. 218-235, „Acta Apostolicae Sedis” 59 (1967) p. 697-704.

19 For many authors since the release of this document can be talked about deacon as the ordinary minister of Holy Communion. Cf. P. Hemperek, Reforma święceń niższych i subdiakonatu, „Prawo Kanoniczne” 16 (1973) no. 3-4, p. 221.

20 Cf. Congregatio Sacri Offici, instructio de cultu mysterii eucharistici Eucharisticum Mysterium, 25.05.1967, no. 31 „Acta Apostolicae Sedis” 59 (1967) p. 539-573 (next EM).

21 Cf. L. Balter, Nadzwyczajny szafarz Eucharystii, „Ruch Biblijny i Liturgiczny” 31 (1978) no. 4, p. 213.

22 Cf. Z. Janczewski, Ustanowienie szafarzy sakramentów świętych w Kościele Eacińskim i Kościołach wschodnich, Warszawa 2004, p. 145. It should be borne in mind that this understanding of ordinary ministers of Holy Communion appears only in the law of Latin Church. In the eastern churches the ordinary minister of Holy Communion is only the bishop and the priest. And deacon is, if the particular law of the Church expresses permission on such a situation. Cf. L. Adamowicz, Wprowadzenie do prawa o sakramentach świętych wedtug Kodeksu Prawa Kanonicznego oraz Kodeksu Kanonów Kościoła Wschodniego, Lublin 1999, p. 106. 
to distribute the Body or the Blood of the Lord ${ }^{23}$. However, to perform this function in this place they need a special permit granted in accordance with the law from the parish priest, rector, or other superior who has the authority at this place, in accordance with the principle in can. CIC 561. The function of ordinary minister always depends on being in a state, in which he has not a prohibited service arising from the ordination, the regulation of Canon Law as a result of having fines or prohibition to perform the ordination ${ }^{24}$.

\section{Circumstances of distributing the Holy Communion.}

The instruction of the Church after the Second Vatican Council ${ }^{25}$ stresses that the receiving of Holy Communion fits in the full participation in the celebration of the Eucharist. So it should take place immediately after the Communion of the priest with the gifts that were consecrated in the event of the Victim, as a symbol of active and godly participation in the Eucharistic Celebration and Sacrifice ${ }^{26}$. This participation in the Holy Mass, after receiving Holy Communion is more and more perfect participation of believers in exercising in the Eucharist and indicates that Holy Communion apart from the Holy Mass is the exception for believers ${ }^{27}$. In this situation, minister of Holy Communion is the priest who serves the Holy Mass. Although other ministers can help breaking Holy Communion, the service of the Eucharist cannot be continued until the distribution of Holy Communion

23 As in the case of exercise by the ministers the sacrament of penance and reconciliation, where to the importance of the adopted action, the special authorization of the competent ecclesiastical authority is required. See CIC, can. 966-976.

Cf. E. Górecki, Najświętsza Eucharystia, p. 95.

25 Earlier, despite the fact that the importance of receiving Holy Communion at the Liturgy of the Holy Mass was emphasized, because of bringing more advantages, Canon Law and Liturgical Law equalized giving Holy Communion during the Mass or before, and immediately after It. Cf. M. Pastuszko, Najświętsza Eucharystia wedtug Kodeksu Prawa Kanonicznego Jana Pawła II, Kielce 1997, p. $172-173$.

Cf. Sacrosanctum Concilium Oecumenicum Vaticanum II, Constitutio de Sacra Liturgia Sacrosanctum Concilium, 4.12.1963, no. 55, „Acta Apostolicae Sedis” 56 (1964) p. 97-138; (next SC); EM 31, 33; IGMR 85.

27 Cf. Cz. Krakowiak, Komunia święta w Kościele Katolickim, [in:] Encyklopedia katolicka, E. Gigilewicz ed., v. 9, Lublin 2002, kol. 497. See EM 31. 
to the faithful is finished, what, of course, could not happen, if the priest of the Mass distributed $\mathrm{It}^{28}$.

Privileged situation when Holy Communion is receiving during the Mass appeared especially in many documents after Vatican Council. The recommendation to give the Holy Communion in the celebration of the Holy Mass is contained in the Encyclical of Paul VI Mysterium Fidei, September 3, 1965, and the instruction of the Congregation of Rites Eucharisticum Mysterium, May 25, 196729. It is also indicated in Komunia świata i kult tajemnicy eucharystycznej poza Msza święta, which explicitly emphasizes that participation in the Eucharist for believers is more effective when the Holy Communion is taken during the Holy Mass. It also teaches about the necessity of educating the faithful to receive Holy Communion during the Eucharistic Sacrifice ${ }^{30}$. Recommendation on receiving Holy Communion within the Eucharist confirms can. 918 CIC.

The Catholic Church Law allows in some cases to receive Holy Communion apart from the Eucharist what expresses can. 918 CIC $^{31}$. The minister in accordance with can. $843 \S 1$ CIC cannot refuse Holy Communion to those who opportunely ask for this Sacrament and are properly disposed and are not prohibited by law from receiving It. So if they ask for the possibility of taking Holy Communion for an important reason, the minister should give it also apart from the Holy Mass $^{32}$. Holy Communion given in that case is provided for those who due to various obstacles cannot take It during the Holy Mass in the community of believers. Those are surely the elderly or sick people ${ }^{33}$. From a formal point of view, the reason for giving Holy Communion

28 Cf. RS no. 88, Pontificia Commissio Codici Iuris Canonici Authentice Interpretando, Responsio ad propositum dubium, 1.06.1988, „Acta Apostolicae Sedis” 80 (1988) p. 1373.

29 See Paulus PPVI, encyclica Mysterium fidei, 3.09.1965, „Acta Apostolicae Sedis” 57 (1965) p. 753-774.; EM 31.

30 Cf. De sacra communione et de cultu mysterii Eucharistici extra Missam. Editio typica, reimpressio emendata. Rituale Romanum ex decreto sacrosancti oecumenici Concilii Vaticani II instauratum auctoritate Pauli PP. VI promulgatum, Città del Vaticano, Typis Polyglottis Vaticanis, 1974, no. 13-14; (next SCCME).

31 CIC 83 can. 918: „It is most strongly recommended that the faithful receive Holy Communion in the course of a Eucharistic celebration. If, however, for good reason they ask for it apart from the Mass, it is to be administered to them, observing the liturgical rites".

32 Cf. RS 91; CIC, can. 915, 918.

33 Cf. P. Petryk, Komunia święta wiernych, „Roczniki Teologiczne” (2006) v. 3, no. 5, p. 287. See RS 129. 
apart from the celebration of the Eucharist, may be the willingness of fulfillment the Eucharistic godliness, expressed in daily receiving Holy Communion. This is the practice of the Church, recommended to all believers, even those who cannot participate in the community Mass or during the celebration are unable to proceed to Holy Communion. It should be remembered that during the liturgical year there are days which are subject to separate normalization. On Great Thursday and Great Friday, the minister may give Holy Communion only during the Liturgy; exceptions are the sick for whom it is possible to provide Holy Communion in their location at any time of the day. And on Holy Saturday the minister can give Holy Communion only in Viaticum ${ }^{34}$. Also, the expression of a request which only executes specified conditions, obliged the minister to provide Holy Communion to faithful apart from the Holy Mass ${ }^{35}$.

Obligation of minister is the note that the limit in taking Holy Communion apart the Holy Mass can become the fact of taking It in that day. The faithful can take Holy Communion second time a day only through full participation in the Eucharist ${ }^{36}$.

Present legislation regulates the conditions of the provision of Viaticum, that is Holy Communion, specified under two or one form to the sick close to death ${ }^{37}$. In Its providing the Church sees the opening of the full Paschal mystery as the key to eternal life and the power of the resurrection, to those who end their earthly life and for this reason imposes on ministers the special duty of this kind of service ${ }^{38}$. Can. 911 CIC indicates that the ministers of the Eucharist in Viaticum are: "to the parish priest, assistant priests it is chaplains and, in respect of all who are in the house, to the community Superior in clerical religious institutes or societies of apostolic life" ${ }^{39}$. This Canon, however, allowed

34 Cf. SCCME 16.

35 Cf.Á. Marzoa, Najświętsza Eucharystia,[in:] Codex Iuris Canonici. Kodeks Prawa Kanonicznego. Komentarz. Edycja polska na podstawie wydania hiszpańskiego, P. Majer ed., Kraków 2011, p. 698.

36 Cf. CIC, can. 917; Pontificia Commissio Codici Iuris Canonici Authentice Interpretando, Responsio ad propositum dubium, 11.07.1984, „Acta Apostolicae Sedis" 76 (1984) p. 746-747; E. Szczot, Prawo wiernego do Eucharystii wedtug Kodeksu Prawa Kanonicznego z 1983 roku, Lublin 2000, p. 109-110.

37 Cf. B. Nadolski, Wiatyk, [in:] Leksykon Liturgii, B. Nadolski ed., Poznań 2006, p. 1672.

38 Cf. Benedictus PP. XVI, Adhortatio Apostolica Postsynodalis De Eucharistia vitae missionisque ECICesiaefonte et culmine Sacramentum Caritatis, 22.02.2007, no. 22, „Acta Apostolicae Sedis” 99 (2007) p. 105-180. 
the ministry of all priests or other ministers of Holy Communion, which can be done with the consent, at least by conjecture, those who the Canon mentioned earlier. If necessary, they can provide It, even without such consent, but they must inform the relevant ministers about it $^{40}$.

Providing Viaticum, in accordance with can. $5303^{\circ} \mathrm{CIC}^{41}$, is the function especially entrusted to the parish priest, which similarly applies with all its consequences for all the ministers listed in can. 911 § 1 CIC. This function assumes his right of superiority to the other priests to perform this ministry or receive information about it when the other minister has fulfilled it. This task defines the obligation of service to the faithful of his own parish priest expressed in order to provide it at the right time, so that the faithful could accept it consciously ${ }^{42}$.

There is also a recommendation that ministers should carry Viaticum within the Holy Mass in order to the faithful experienced by disease could receive Holy Communion in two forms. In that way it is easier to understand that Viaticum, as the ministry servicing by the community of the Church to the believer in a state of agony, is a special sign of participation of this faithful through Holy Communion in the mystery of death and the transition of Christ to God the Father ${ }^{43}$.

\section{Ministry of legally established acolyte}

Among the commissioners to give Holy Communion there are also the extraordinary minister. The codec of Canon Law in Canon 910, among the extraordinary ministers first defines acolyte as person who can distribute Holy Communion ${ }^{44}$. According to can. $230 \S 1$ acolyte is

40 Cf. J. Nowak, Prawo w stużbie wydarzeń zbawczych. Zarys prawodawstwa liturgicznego, Poznań 2004, p. 15.

41 CIC, Can. 530: „The functions especially entrusted to the parish priest are as follows:”, the third point listed: „the administration of Viaticum".

42 Cf. Á. Marzoa, Najświętsza Eucharystia, p. 690.

43 Cf.SC27. The value of Viaticum as the most important service, which the Church commits to the dying believer, by his assimilation to Christ, is, next to the symbol of the two characters of Holy Communion, also stressed by the sequence of provision of the sacraments to the patient different from it was foreseen by the rites until the Second Vatican Council. Currently they are available in this order, confession, and unction and Viaticum, not like earlier confession, Viaticum and unction. Cf. W. Bomba, Kult eucharystyczny poza Msza święta, [in:] Mysterium Christi, W. Świerzawski ed., v. 3, Msza święta, Kraków 1992, p. 336.

44 The word ,acolyte” is a technical term used in the Catholic Church. It comes from the Greek word akólouthos, what means ,associate”. This word also means a person who-related, especially, accompanying as a supporter. Cf. Akolita, 
a man who was called to the ministry by the special liturgical rites to support the priest and the deacon ${ }^{45}$.

The ministry (ministerium) of acolyte fits to the liturgical functions mentioned in can. $230 \mathrm{CIC}^{46}$, which divides them into: stable ministry, temporary assignment, and extraordinary functions (munus), acting instead of the Holy ministers ${ }^{47}$. The ministry of acolyte is emphasized among these functions, because the meaning of the acolyte was underlined not only by its permanent character or fulfilling as a replacement, but, above all, by introducing in the norm of Canon Law, which allowed the acolyte to give Holy Communion ${ }^{48}$.

\section{Legally established of acolyte}

The origin of beginning of the modern forms of acolyte ministry can be seen in Council postulate to renew the sacrament of ordination ${ }^{49}$ and in difficulties in some countries in receiving Holy Communion by the faithful, caused by the lack of priests or deacons which appeared after Second Vatican Council ${ }^{50}$. Opposite these needs came Pope Paul VI,

[in:] Wielki słownik wyrazów obcych i trudnych, A. Markowski, R. Pawelec eds., Warszawa 2001, p. 28.

Cf. E. Górecki, Najświętsza Eucharystia, p. 96.

Norm, indicating the participation of the lay men in the liturgical service begins with the entry: "Lay men whose age and talents meet the requirements prescribed by decree of the Episcopal Conference, can be given the stable ministry of lector and of acolyte, through the prescribed liturgical rite. This conferral of ministry does not, however, give them a right to sustenance or remuneration from the Church". CIC, can. $230 \S 1$.

Also IGMR on the first place among the ministers of the Liturgy mentioned the acolytes. Cf. IGMR 98.

Cf. L. Gerosa, Prawo Kościoła, trans. I. Pękalski, Poznań 1999, p. 171.

This postulate is clearly expressed in the Constitution Sacrosanctum Concilium which claims that it is needed to re-develop the Ordination of Rites, both the ceremonies and the texts of the sacraments. Cf. SC 76. New ordination of rites were included in Pontyfikat Rzymski on June 18, 1968. See De Ordinatione Episcopi, Presbyterorum et Diaconorum. Editio typica altera. Pontificale Romanum ex decreto Sacrosancti Oecumenici Concilii Vaticani II instauratum auctoritate Pauli PP. VI editum Ioannis Pauli II PP, cura recognitum, Città del Vaticano, Typis Polyglottis Vaticanis, 1990.

50 First prognostic of the introduction of the extraordinary ministers of Holy Communion was, released on April 30, 1969 by the Congregation of the Sacraments, the leadership of Fidei custos, which allowed to apply by the superiors of the particular Churches to the Apostolic See for permission which let them, in special situations, identify individuals as the ministers of Holy Communion. Cf. B. Margański, Nadzwyczajny szafarz Komunii świętej, [in:] Misterium Christi. 
who on August 15, 1972 published Motu Proprio Ministeria quaedam, changing the law on the sacrament of ordination ${ }^{51}$. He canceled in it lower ordinations and subdiaconate, and instituted the ministry of lector and acolyte.

Acolyte, in accordance with point IX of the mentioned Motu proprio, is provided as a ministry to those who will be assigned by their ordinary, that is, bishop or the superior of religious institutes. This ministry is provided in accordance with the rite: De institutione lectorum et acolythorum. De admission inter candidatos ad diaconatum et presbyteriatum. De sacro caelibatu amplectendo ${ }^{52}$. It is given to those men who are preparing to accept the ordination, and those that remain in the secular state, but their service is needed in the Church community ${ }^{53}$. By assigning a ministry of acolyte or lector, as required road leading to the sacrament of ordination, it is stressed the deletion from the official ministry the participation of women ${ }^{54}$.

Definition of requirements to permitted ministry of acolyte from the beginning of the introduction of this service was clearly transferred to the competence of the Conference of Bishops. Motu Proprio Ministeria quaedam only defines the requirement of the request to the Ordinary that needs to appoint them, as well as the determination of devotional service to God and service to the people of the Christian ${ }^{55}$. And other qualities, including age, are determined by particular Conferences of Bishops.

\section{The character of the ministry of acolyte}

The specifics of the service which the Church gives acolyte, is expressed in the rites for the performance of which he is entitled. His

Sakramenty i sakramentalia, W. Świerzawski ed., Zawichost - Kraków - Sandomierz 2013, p. 103.

51 See Paulus PP VI., Motu proprio Ministeria quaedam, 15.08.1972, „Acta Apostolicae Sedis" 64 (1972) p. 529-534.

52 See Pontificale Romanum ex decreto Sacrosancti Oecumenici Concilii Vaticani II instrauratum auctotitate Pauli PP. VI promulgatum. De institutione lectorum et acolythorum. Deadmission inter candidatos ad diaconatum et presbyteriatum. De sacro caelibatu amplectendo, edition typical. Typis Polyglottis Vaticanis 1973.

Cf. M. Pastuszko, Szafarz Eucharystii, „Prawo Kanoniczne” 40 (1987) no. 3-4, p. 39,42 .

54 See B. Lüdicke, Liturgie und Recht. Beitrag zu einer Verhältnisbestimmung, [in:] Liturgie - ein vergessenes Thema der Theologie?, K. Richter ed., Freiburg - Basel - Wien $1987^{2}$, p. 172-184.

$55 \quad$ Cf. Paulus PP VI., Motu proprio Ministeria quaedam, p. VIII. 
tasks during the celebration of the Liturgy are helping priests and deacons: carrying of the cross in the procession of the entrance, assistance during the celebration by introducing all the items needed for worship, such as liturgical books, water, incense, liturgical utensils and other ${ }^{56}$. In this sense, they also have the possibility of holding the Vigil to the deceased and conduct a funeral station in the house of the deceased and the cemetery, of course, when there is no priest or deacon ${ }^{57}$.

There are some authorization belonging to acolyte which are obviously connected with the cult of the Eucharist that set them apart from other extraordinary ministers of the Eucharist, because they cannot exercise them. They are the exposure and covering the Holy Sacrament, although he cannot do the blessing of the Holy Sacrament. This right can always be suspended by the diocesan bishop ${ }^{58}$. Similar activities, being service at the altar, which directly is allowed the acolyte, is performing purification, when there is no deacon, even in the celebration of the Holy Mass ${ }^{59}$.

The third executive statement to the Constitution on the Liturgy of the Second Vatican Council Liturgica Instaurationes from September $25,1970^{60}$, introduces to the acolytes the possibility of serving the goblet, when Holy Communion is given under the two characters, and the Blood of the Lord is given to believers from the goblet. Basically, the acolyte is a servant of the altar, being the assistant of priests and deacons in their liturgical actions. At the top of this there is the possibility of distributing Holy Communion to the faithful ${ }^{61}$.

Ministry of acolyte in an the extraordinary minister of Holy Communion apart from the Holy Mass can appeared only in situation, when the ordinary ministers, such as bishop, priest or deacon, are absent.

56 Cf. IGMR 187-193.

57 Cf. Ordo exsequiarum. Editio typica. Rituale Romanum ex decreto sacrosancti oecumenici Concilii Vaticani II instauratum auctoritate Pauli PP. VI promulgatum, Città del Vaticano: Typis Polyglottis Vaticanis, 1969, no. 19.

58 Cf.Komuniaświętaikult tajemnicyeucharystycznejpoza Msząświęta, Katowice 1985, no. 67, p. 41; Konferencja Episkopatu Polski, Instrukcja w sprawie udzielania postugi lektora i akolity świeckim mężczyznom, 2.10.2007, „Anamnesis” 52 (2008), no. 6, 17.

59 Cf. Konferencja Episkopatu Polski, Dyrektorium Duszpasterstwa Stużby Liturgicznej, 27.11.2008, Kraków 2009, no. 37; IGMR 192

60 See Sacra Congregatio Pro Cultu Divino, instructio tertia ad constitutionem de sacra liturgia recte exsequendam Liturgicae instaurationes, 5.09.1970, „Acta Apostolicae Sedis" 62 (1970) p. 692-704.

61 Cf. Konferencja Episkopatu Polski, Dyrektorium Duszpasterstwa Stużby Liturgicznej, no. 37. 
Although the ordinary minister is present, however, he cannot give Holy Communion because he is ill, old or takes other pastoral duties at this time. A situation that allows the acolyte the provision of Holy Communion is also helping the minister, who gives believers the Holy Communion, but those wishing to join the Gods Table are so many that the liturgical celebration could significantly be extended. Helping the minister and his bad condition also points to the need for ministry acolyte in the celebration of the Holy Mass ${ }^{62}$.

Opinion of the situations if the acolyte should be allowed for the ministry by the provision of Holy Communion make the proper priest of the place of that ministry, that is, the parish priest or rector of the $\operatorname{church}^{63}$.

After the ministry of acolyte there came doubt if he could give Holy Communion to the sick in their homes or other places outside the church and Viaticum to dying. Doubt was explained by allowing acolyte this kind of ministry what was argued that there are some obstacles of ordinary ministers and good of believers, especially in the case of the need to adopt Viaticum. Finally doubts were dispelled by appropriate notes in the Roman Ritual in the parts dedicated to the distribution of Holy Communion and worship of the Eucharist apart the Holy Mass. In these books, there was found the entry about rites, adapted to providing Holy Communion by the extraordinary ministers, including acolyte ${ }^{64}$.

The ministry, implemented by acolyte, expressing in the service of the altar of the Lord and faithful, requires from received the ministry involvement in all what concerns the service of God, through the inner and spiritual understanding of the importance of it all that serve in the Church. It is expected the acolyte sacrifices to God and to other believers every day, and are an example of seriousness and sense of the sacred in the Church, and also is distinguished a love for God's people, especially to the sick, where he is sent in a spirit of service ${ }^{65}$.

62 Cf.M.Pastuszko, Najświętsza Eucharystia wedtug Kodeksu Prawa Kanonicznego Jana Pawta II, p. 118.

${ }_{63}$ Cf. J. Dyduch, Postugi liturgiczne świeckich $w$ posoborowym prawodawstwie polskim, „Ruch Biblijny i Liturgiczny” 64 (20111) no. 1, p. 30.

64 Cf. M. Pastuszko, Szafarz Eucharystii, p. 43.

65 Cf. Paulus PP VI., Motu proprio Ministeria quaedam, p. V; IGMR 99; Konferencja Episkopatu Polski, Instrukcja w sprawie udzielania postugi lektora $i$ akolity świeckim mężczyznom, no. 6. 


\section{The extraordinary ministers established if necessary}

The Church legislator in can. 910 CIC among the extraordinary ministers mentions also the lay men who are not acolytes. The extraordinary ministers are the lay men that in the case of urgent need of minister were ordained to the distribution of Holy Communion by the specific liturgical rite. The rite can be made by the diocesan bishop or the priest whom the bishop has authorized because of an unpredictable and individual cases ${ }^{66}$. Entrusting this liturgical service to the secular persons is based on the dignity from the adopted ordinances of Holy baptism and not from any participation in the dignity of the sacrament of ordination. Lay men are here understood only as assistants at giving Holy Communion in case of need of such help ${ }^{67}$.

\section{The provision of Holy Communion by the extraordinary minister}

Except to performing ministry, secular acolyte are admitted to the tasks of the extraordinary ministers of Holy Communion in the instruction Immensae caritatis, published by the Congregation of the Sacraments on January 29, $1973^{68}$. The publication of such order was due to the concern of the Church about those believers who for lack of ordinary ministers are unable to take Holy Communion, or this opportunity would be for them very difficult to realization ${ }^{69}$. The motivation of the admission of lay men to such a big dignity can also be found in postcouncil look at reality community of Church and the implementation of its Liturgy. In this ecclesiology it is emphasized that

66 $\quad$ Cf. J. Dyduch, Udziat świeckich w potrójnej misji Kościoła w świetle instrukcji ECICesiae de Mysterio,[in:] Kapłaństwo powszechne a kaptaństwo hierarchiczne. Materiaty spotkania wykładowców prawa kanonicznego, A. Kaczor ed., Lublin 1998, p. 47.

67 Cf. M. Kunzler, Liturgia Kościoła, trans. L. Balter, Poznań 1999, p. 266.

68 See Sacra Congregatio de Disciplina Sacramentorum, instructio de communione sacramentali quibusdam in adiunctis faciliore reddenda Immensae Caritatis, 29.01.1973, „Acta Apostolicae Sedis” 65 (1973) p. 264-271 (next IC).

69 Practice of distributing Holy Communion by lay men, was already known in the Church of the first centuries. Evidence of such practices appears in the VIII century. Breaking Holy Communion by the lay men was due to the fact that after Holy Mass, if there was no current deacons or acolytes, faithful carried the consecrated bread to the sick. In the IX century there was already a regulation in the Church Law reserved giving Holy Communion to the priest, and when he is not present, to deacons. Cf. Cz. Krakowiak, Nadzwyczajni szafarze Komunii świętej $w$ archidiecezji lubelskiej, „Wiadomości Archidiecezji Lubelskiej” 49 (1995) no. 4, p. 111. 
all belonging to the Church in virtue of baptism are equal in dignity and action ${ }^{70}$. All baptized believers participate in priestly, prophetic and kingly mission of Christ. Lay men thus, because of the acceptance of baptism have the right to active participation in the Liturgy of the Church, and, in addition, to proper perform the worship of God, celebrated by the Church ${ }^{71}$. This can be done also in areas such as the provision of Holy Communion that are assigned to the ordinary minister, and in a situation of need, are evidence of relations between states in the Church and a desire to help their priests by the lay men ${ }^{72}$.

Instruction Immensae caritatis, which gave ordinaries the right to determine the lay men, performing tasks the extraordinary minister of Holy Communion, but also filed conditions in which it can be used. These conditions were determined by enumeration the specific circumstances, i.e. when there is no priest, deacon and acolyte, and mentioned above, cannot give Holy Communion because of other pastoral ministry, the lack of health or old age, and the number of believers entering into Holy Communion is so great that the Mass or the distributing of the Eucharist apart the Mass would last longer ${ }^{73}$. One can distinguish two main reasons for granting such permission the lay men. The first is concern for the spiritual well-being, wishing to take Holy Communion in the absence of ordinary ministers. The second is assistance with difficulties in giving the Holy Sacrament, caused by the ordinary minister. These both circumstances, by their nature, can take place as a part of the Holy Mess and also apart It. Apart from the Holy Mass authorization to give the Holy Communion by the extraordinary ministers have been appointed in a situation when carrying Viaticum to the sick involves overcoming large distances or there are a large number of believers who, because of their illness, want to receive Holy Communion outside of the Church. This operation should not last too long, what requires not always existing circumstances: a large number of the ordinary ministers or their full devotion to this ministry. Vocation of the extraordinary ministers, is here another, real way of redemption of this need ${ }^{74}$.

$70 \quad$ Cf. CIC, can. 208.

71 Cf. SC 28; CIC, can. 214.

72 Cf. LG 32, 37; DA 6, 25; VII Zwyczajny Synod Biskupów z 1987 r., Lineamenta (1985), no. 17-18, [in:] Powołanie i postannictwo ludzi świeckich w świetle dokumentów kościelnych, E. Weron ed., Poznań 1989, p. 27-28.

73 Cf. IC 1.

74 Cf. W. Kazimieruk, Aktualizacja kapłaństwa wspólnego w liturgii w świetle dokumentów odnowy soborowej, Siedlce 2001, p. 91-92. 
In connection with popularity of vocation of the extraordinary ministers in the west of Europe and the emerging of frequent abuse in their ministry, there appeared some doubts to the conditions in which their help is actually justifiable. The Pontifical Commission for Authentic Interpretation of Code of Canon Law, in the plenary session on, February 20, 1987 explained some of the issues relating to the definition of situations in which the extraordinary ministers can be active ${ }^{75}$. The Commission found unequivocally that if in the Church there are the ordinary ministers, whether priests or deacons who are not in the situation of some barriers, the extraordinary ministers cannot perform their function. The restriction applies both to the acolytes, and secular ministers appointed in case of need. In the speech of the Pontifical Commission emphasized the fact that the task of the extraordinary ministers always replaces the task of the ordinary ministers ${ }^{76}$. Therefore, it is determined that giving Holy Communion by the extraordinary minister cannot become the norm and can never be abused ${ }^{77}$.

\section{Admittance to functions of the extraordinary minister}

Depending on the type of the extraordinary minister there are different modes of access to perform this liturgical function. It should be borne in mind that the can. $910 \S 3 \mathrm{CIC}$, distinguishes the extraordinary ministers on acolytes and designated lay men. Lay men who are not acolytes must be dedicated in accordance with can. $230 \S 3$ on the principle of the fulfillment of certain responsibilities of the ministers in their replacement, among which the norm being consider enumerates giving the Holy Communion. Such appointment can be made only when it is necessary, and there is no competent ministers. This division of the acolytes, and the lay men admitted to the duties of ministers are not derived from the diversity of situations in which the extraordinary ministers can fulfill their functions, but because of the fact, how to charge this function. The separation between them is manifested in the fact that the acolytes are dedicated to be the extraordinary ministers in the framework of the entrusted ministry, while others of the lay

75 See Pontificia Commissio Codici Iuris Canonici Authentice Interpretando, Responsio ad propositum dubium, 1.06.1988, p. 1373. świętej, „Poznańskie Studia Teologiczne” 10 (2001) p. 331-332.

77 Cf. Congregatio pro Clericis et Aliae, instructio de quisdam questionibus circa fidelium laicorum cooperationem sacerdotum ministerium spectantem Ecclesiae de Mysterio, 15.08.1997, „Acta Apostolicae Sedis” 89 (1997) p. 872-877. 
men are called to the functions of ministers ad hoc. The function of the extraordinary ministers has institutional connection to the ministry of the acolytes. In other cases, the competent ecclesiastical authority appoints lay men to giving Holy Communication to secular people within occurring need caused by the lack of ordinary ministers ${ }^{78}$.

The competent authority in assigning the functions of ministers is ordinary of the place, who may allow the lay man, non-acolyte, to take over functions of the extraordinary minister of Holy Communion in the territory of the local Church. He can make orders for specific cases (ad actum), or at temporary time (ad tempus), or even at permanent time, but always when it is necessary and occurs in the community of believers where he is executive. The authorization of the ordinary of the place may be entrusted by him to the auxiliary bishop, assistant priest or Episcopal delegate, and even participating in ministry priests. When there is the last of these circumstances, the entrusting authority is personal, never general. Thus, the authorities established the extraordinary minister can also be instructed only for personal case, when it comes to the case of satisfaction of a real need arising from the situation of the local community entrusted to such priest ${ }^{79}$.

For example, in the context of the Church in Poland, Mszat Rzymski from 1975, which is reiterated in Mszat Rzymski dla diecezji polskich from 1986, released in the Polish language, contain annotation which permit the lay men to disposable distribution of Holy Communion, noting also that the ordinaries of places can allow the priests this entrusting ${ }^{80}$. The actual introduction of the possibility of appointing lay men to functions of the extraordinary minister of Holy Communion in Poland, except an acolyte, took place on the 240 Plenary Conference of the Episcopate of Poland on May 2, 1990. The Polish bishops have determined that this function will be entrusted only men aged 35 to 65 years old ${ }^{81}$. And the authority of priests to provide single permission

78 Cf. CIC, can. 230 § 3; A. Sobczak, Zastępczy charakter funkcji nadzwyczajnego szafarza komunii świętej, p. 335.

79 Cf. Á. Marzoa, Najświętsza Eucharystia, p. 689.

$80 \quad$ Cf. Dodatek. Upoważnienie dojednorazowego rozdawania Komunii świętej, [in:] Mszat dla diecezji polskich, Poznań 1986, p. (6).

81 Cf.PismoSekretariatu Prymasa Polski, 5.05.1990, no. 1311/90/P. After publishing this rule, there were some instructions which accurately define the way of realization of functions of the extraordinary ministers. See Konferencja Episkopatu Polski, Instrukcja w sprawie formacji i sposobu wykonywania postugi nadzwyczajnych szafarzy Komunii świętej, 22.06.1991, [in:] Dokumenty duszpastersko-liturgiczne Episkopatu Polski(1966-1993), Cz. Krakowiak, L. Adamowicz eds., Lublin 1994, p. 75-83. 
to the lay man to give Holy Communion appeared with the release of Interdicasterial instruction on certain questions regarding the collaboration of the secular faithful in the ministerial service of priests Ecclesiae de mysterio from $1997^{82}$. Currently, there are directives of the Conference of the Episcopate of Poland contained in documents: Wskazania odnośnie do nadzwyczajnego szafarza Komunii św., March 9, $2006^{83}$, and Modyfikacja instrukcji w sprawie formacji i sposobu wykonywania postugi nadzwyczajnych szafarzy Komunii św. z dnia 22 VI $1991 r$., released on October 18, 2006 ${ }^{84}$. In accordance with these rules, lay men can be ordained to the function of the extraordinary minister of Holy Communion by the diocesan bishop within their own diocese for a year, after recommending a particular candidate by his parish priest. The extraordinary minister can be a man as well as the nun and the woman consecrated life, from 25 to 65 years old, if they know the truths of faith and theological-liturgical rules and are characterized as an exemplary Catholic. In the matter of fulfilling the function, they must always correspond with the parish priest, and during the Holy Mass are required to wear a matching suit, that for lay men it is an alba ${ }^{85}$.

\section{Conclusion}

In legal discipline of Latin Catholic Church there is significant division among the ministers to give Holy Communion on the ordinary and extraordinary ministers. That division is not only in determining rights and obligations, but it is the opportunity to see a wealth of functions in the Church system. It should be borne in mind that in current form of canonical law both groups can perform their task within the Holy Mass and apart from It. The ordinary minister is a bishop, priest and deacon. The extraordinary minister is the acolyte and the lay man, who, to perform the duties instead of the other ministers, was entitled

$82 \quad$ Cf. Congregatio pro Clericis et Aliae, instructio de quisdam questionibus circa fidelium laicorum cooperationem sacerdotum ministerium spectantem Ecclesiae de Mysterio, art. 8, § 1.

83 See Konferencja Episkopatu Polski, Wskazania Konferencji Episkopatu Polski odnośnie nadzwyczajnego szafarza Komunii świętej, 9.03.2006, „Anamnesis” 46 (2006) p. 17-18.

84 See Konferencja Episkopatu Polski, Modyfikacja instrukcji w sprawieformacji i sposobu wykonywania postugi nadzwyczajnego szafarza Komunii świętejz dnia 22 VI 1991 r., 18.10.2006, „Anamnesis” 48 (2007) p. 10-14.

85 Cf. Konferencja Episkopatu Polski, Wskazania Konferencji Episkopatu Polski odnośnie nadzwyczajnego szafarza Komunii świętej, no. 1-9. 
in accordance with the law ${ }^{86}$. Although there is a difference between the extraordinary ministers, however, it is not resulted in the diversity of situations in which the minister can perform their functions, but in the way of entrusting this function and some existing competence. The acolyte is permanently assigned to serve at the altar, including, when there is a real need, giving Holy Communion as the ministry of the extraordinary minister. Lay man, except acolyte, is permitted to give Holy Communion and is also the extraordinary minister, but his function is vicarious and arises only in a situation when there is no possibility of the service of the ordinary minister. Special circumstance of provision Viaticum is distinguished by the fact that the ministers, in that situation, are the parish priest, assistant priests, chaplain, and some of the superiors of religious institutes, but when it is necessary or with appropriate agreement other ministers ordinary and extraordinary are them as well. That shows the great care that the sick and the dying are surrounded by the Church.

\section{DUCHOWNY, AKOLITA I ŚWIECKI WYZNACZANY W PRZYPADKU KONIECZNOŚCI JAKO SZAFARZE KOMUNII ŚW.}

Szafarzem Komunii św. jest ten kogo prawodawstwo liturgiczne dopuszcza do spełniania tego zadania Istnieje podział na szafarzy zwyczajnych, jakimi są: biskup, prezbiter i diakon oraz na szafarzy nadzwyczajnych, którymi są akolici i świeccy wyznaczeni do swej posługi w zastępstwie innych szafarzy. Szafarze zwyczajni mogą wykonywać swą posługę, jeśli tylko nie zabrania im tego prawo w wyniku nałożonych kar lub zakazów. Natomiast, by mógł rozdzielać Komunię św. szafarz nadzwyczajny, musi zaistnieć sytuacja, która uniemożliwia działanie szafarzy zwyczajnych, jak ich choroba, inne posługi czy zbyt mała ich liczba względem pragnących przystąpić do Komunii św. Szafarzem nadzwyczajnym Komunii św. jest również Akolita, co wynika z natury jego przypisania do posługi przy ołtarzu. Jeśli Komunia św. jest udzielana na sposób Wiatyku, szafarzami są: proboszcz, wikariusz, kapelan i niektórzy przełożeni w instytutach zakonnych. W sytuacjach konieczności lub za zgodą wymienionych szafarzy, taką posługę mogą dokonywać inni szafarze zwyczajni i nadzwyczajni.

Słowa kluczowe: szafarz Komunii św., akolita, szafarz nadzwyczajny, Wiatyk, uprawnienie.

$86 \quad$ Cf. CIC, can. $910 \S 1$ i 2 i can. $230 \S 3$. 


\section{Bibliography:}

1. Adamowicz L., Wprowadzenie do prawa o sakramentach świętych wedtug Kodeksu Prawa Kanonicznego oraz Kodeksu Kanonów Kościoła Wschodniego, Lublin 1999.

2. Akolita, [in:] Wielki stownik wyrazów obcych i trudnych, A. Markowski, R. Pawelec eds., Warszawa 2001, p. 28.

3. Balter L., Nadzwyczajny szafarz Eucharystii, „Ruch Biblijny i Liturgiczny” 31 (1978) no. 4, p. 207-214.

4. Benedicti PP. XVI, adhortatio apostolica postsynodalis de Eucharistia vitae missionisque Ecclesiae fonte et culmine Sacramentum caritatis, 22.02.2007, „Acta Apostolicae Sedis” 99 (107) p. 104-180.

5. Bomba W., Kult eucharystyczny poza Msza świętą, [in:] Mysterium Christi, W. Świerzawski ed., v. 3, Msza święta, Kraków 1992, p. 325-347.

Canon law

6. Codex Iuris Canonici auctoritate Ioannis Pauli PP. II promulgatus, Vatican 1984

7. Congregatio de Cultu Divino et Disciplina Sacramentorum, instructio de quibusdam observandis et vitandis circa sanctissimam Eucharistiam. Redemptionis sacramentum, 25.03.2004, „Acta Apostolicae Sedis” 96 (2004), p. 549-601.

8. Congregatio pro Clericis et Aliae, instructio de quisdam questionibus circa fidelium laicorum cooperationem sacerdotum ministerium spectantem Ecclesiae de Mysterio, 15.08.1997, „Acta Apostolicae Sedis” 89 (1997) p. 852-877.

9. Congregatio Sacri Offici, instructio de cultu mysterii eucharistici Eucharisticum Mysterium, 25.05.1967, „Acta Apostolicae Sedis” 59 (1967) 539-573.

10. De Ordinatione Episcopi, Presbyterorum et Diaconorum. Editio typica altera. Pontificale Romanum ex decreto Sacrosancti Oecumenici Concilii Vaticani II instauratum auctoritate Pauli PP. VI editum Ioannis Pauli II $P P$, cura recognitum, Città del Vaticano, Typis Polyglottis Vaticanis, 1990.

11. De sacra communione et de cultu mysterii Eucharistici extra Missam. Editio typica, reimpressio emendata. Rituale Romanum ex decreto sacrosancti oecumenici Concilii Vaticani II instauratum auctoritate Pauli PP. VI promulgatum, Città del Vaticano, Typis Polyglottis Vaticanis, 1974.

12. Dyduch J., Postugi liturgiczne świeckich $w$ posoborowym prawodawstwie polskim, „Ruch Biblijny i Liturgiczny” 64 (20111) no. 1, p. 26-32.

13. Dyduch J., Udziat świeckich w potrójnej misji Kościoła w świetle instrukcji Ecclesiae de Mysteriao, [in:] Kapłaństwo powszechne a kapłaństwo hierarchiczne. Materiaty spotkania wykładowców prawa kanonicznego, A. Kaczor ed., Lublin 1998, p. 43-53.

14. Gerosa L., Prawo Kościoła, trans. I. Pękalski, Poznań 1999.

15. Górecki E., Najświętsza Eucharystia, [in:] Komentarz do Kodeksu Prawa Kanonicznego, W. Góralski, E. Górecki, J. Krukowski, J. Krzywda, P. Majer, B. W. Zubert eds., v. 3/2, book VI, Uświęcające zadanie Kościoła, Lublin 2011, p. 83-140.

16. Hemperek P., Najświętsza Eucharystia, [in:] Komentarz do Kodeksu Prawa Kanonicznego z 1983, P. Hemperek, W. Góralski, F. Przytuła, J. Bakalarz eds., v. 3, Lublin 1986, p. 112-149. 
17. Hemperek P., Reforma święceń niższych i subdiakonatu, „Prawo Kanoniczne" 16 (1973) no. 3-4, p. 209-228.

18. Institutio Generalis Missalis Romani, [in:] Missale Romanum, editio typica altera, 27.03.1975, Typis Polyglottis Vaticanis 1975.

19. Ioannes Paulus PP. II, epistula de sacrosanctum Eucharistiae mysterio et cultu Dominicae Cenae, 24.02.1980, „Acta Apostolicae Sedis” 72 (1980) p. 113-133.

20. Ioannis Pauli PP. II, Catechismus Catholicae Ecclesiae, Vatican 1992.

21. Janczewski Z., Ustanowienie szafarzy sakramentów świętych w Kościele Łacińskim i Kościołach wschodnich, Warszawa 2004.

22. Kazimieruk W., Aktualizacja kapłaństwa wspólnego w liturgii w świetle dokumentów odnowy soborowej, Siedlce 2001.

23. Konferencja Episkopatu Polski, Dyrektorium Duszpasterstwa Stużby Liturgicznej, 27.11.2008, Kraków 2009.

24. Konferencja Episkopatu Polski, Instrukcja w sprawie formacji i sposobu wykonywania postugi nadzwyczajnych szafarzy Komunii świętej, 22.06.1991, [in:] Dokumenty duszpastersko-liturgiczne Episkopatu Polski (1966-1993), Cz. Krakowiak, L. Adamowicz eds., Lublin 1994, p. 75-83.

25. Konferencja Episkopatu Polski, Instrukcja w sprawie udzielania postugi lektora i akolity świeckim mężczyznom, 2.10.2007, „Anamnesis” 52 (2008), p. 41-45.

26. Konferencja Episkopatu Polski, Modyfikacja instrukcji w sprawie formacji i sposobu wykonywania postugi nadzwyczajnego szafarza Komunii świętej $z$ dnia 22 VI 1991 r., 18.10.2006, „Anamnesis” 48 (2007), p. 10-14.

27. Konferencja Episkopatu Polski, Wskazania Konferencji Episkopatu Polski odnośnie nadzwyczajnego szafarza Komunii świętej, 9.03.2006, „Anamnesis" 46 (2006) p. 17-18.

28. Kongregacja do spraw duchowieństwa, Kapłan głosiciel słowa, szafarz sakramentów $i$ przewodnik wspólnoty $w$ drodze do trzeciego tysiaclecia chrześcijaństwa, 19.03.1999, Watykan 1999.

29. Krakowiak Cz., Komunia święta w Kościele Katolickim, [in:] Encyklopedia katolicka, E. Gigilewicz ed., v. 9, Lublin 2002, kol. 494-510.

30. Krakowiak Cz., Nadzwyczajni szafarze Komunii świętej w archidiecezji lubelskiej, „Wiadomości Archidiecezji Lubelskiej” 49 (1995) no. 4, p. 107-117.

31. Kunzler M., Liturgia Kościoła, transl. L. Balter, Poznań 1999.

32. Lüdicke K., Liturgie und Recht. Beitrag zu einer Verhältnisbestimmung, [in:] Liturgie - ein vergessenes Thema der Theologie?, K. Richter ed., Freiburg - Basel - Wien $1987^{2}$, p. 172-184.

33. Margański B., Nadzwyczajny szafarz Komunii świętej, [in:] Misterium Christi. Sakramenty i sakramentalia, W. J. Świerzawski ed., Zawichost Kraków - Sandomierz 2013, p. 97-112.

34. Marzoa Á., Najświętsza Eucharystia, [in:] Codex Iuris Canonici. Kodeks Prawa Kanonicznego. Komentarz. Edycja polska na podstawie wydania hiszpańskiego, P. Majer ed., Kraków 2011, p. 680-718.

35. Nadolski B., Komunia eucharystyczna, [in:] Leksykon Liturgii, B. Nadolski ed., Poznań 2006, p. 1672-1676. 
36. Nadolski B., Wiatyk, [in:] Leksykon Liturgii, B. Nadolski ed., Poznań 2006, p. 1672-1676.

37. Nowak J., Prawo w stużbie wydarzeń zbawczych. Zarys prawodawstwa liturgicznego, Poznań 2004.

38. Nowak J., Trójstopniowość sakramentu święceń, [in:] Kapłaństwo, K. Czulak, L. Balter, P. Góralczyk eds., Poznań 1988, p. 94-112.

39. O'Collins G., E. Farrugia ed., Leksykon pojęć teologicznych i kościelnych, transl. J. Ożóg, Kraków 2002.

40. Ordo exsequiarum. Editio typica. Rituale Romanum ex decreto sacrosancti oecumenici Concilii Vaticani II instauratum auctoritate Pauli PP. VI promulgatum. Città del Vaticano: Typis Polyglottis Vaticanis, 1969.

41. Ozorowski E., Szafarz sakramentów, [in:] Stownik podstawowych pojęć teologicznych, E. Ozorowski ed., Warszawa 1997, p. 278-279.

Canon law

42. Pastuszko M., Najświętsza Eucharystia wedtug Kodeksu Prawa Kanonicznego Jana Pawta II, Kielce 1997.

43. Pastuszko M., Szafarz Eucharystii, „Prawo Kanoniczne” 40 (1987) no. 3-4, p. 29-48.

44. Paulus PP VI., Motu proprio Ministeria quaedam, 15.08.1972, „Acta Apostolicae Sedis" 64 (1972), p. 529-534.

45. Paulus PP. VI, encyclica Mysterium fidei, 3.09.1965, „Acta Apostolicae Sedis" 57 (1965) p. 753-774.

46. Paulus PP. VI, motu proprio Sacrum diaconatus ordinem, 18.06.1967, „Acta Apostolicae Sedis" 59 (1967) p. 697-704.

47. Petryk P., Komunia święta wiernych, „Roczniki Teologiczne” (2006) v. 3, no. 5 , p. 265-287.

48. Pius PP. XII, encyclica Mediator Dei, „Acta Apostolicae Sedis” 39 (1947) p. 521-595..

49. Pontificale Romanum ex decreto Sacrosancti Oecumenici Concilii Vaticani II instrauratum auctotitate Pauli PP. VI promulgatum. De institutione lectorum et acolythorum. De admission inter candidatos ad diaconatum et presbyteriatum. De sacro caelibatu amplectendo, edition typical. Typis Polyglottis Vaticanis 1973.

50. Pontificia Commissio Codici Iuris Canonici Authentice Interpretando, Responsio ad propositum dubium, 11.07.1984, „Acta Apostolicae Sedis” 76 (1984), p. 746-747.

51. Pontificia Commissio Codici Iuris Canonici Authentice Interpretando, Responsio ad propositum dubium, 1.06.1988, „Acta Apostolicae Sedis” 80 (1988), p. 1373.

52. Sacra Congregatio de Disciplina Sacramentorum, instructio de communione sacramentali quibusdam in adiunctis faciliore reddenda Immensae Caritatis, 29.01.1973, „Acta Apostolicae Sedis” 65 (1973), p. 264-271.

53. Sacra Congregatio Pro Cultu Divino, instructio tertia ad constitutionem de sacra liturgia recte exsequendam Liturgicae instaurationes, 5.09.1970, „Acta Apostolicae Sedis” 62 (1970), p. 692-704.

54. Sacrosanctum Concilium Oecumenicum Vaticanum II, Constitutio de Sacra Liturgia Sacrosanctum Concilium, 4.12.1963, „Acta Apostolicae Sedis" 56 (1964), p. 97-138; 
55. Sacrosanctum Concilium Oecumenicum Vaticanum II, Constitutio dogmatica de Ecclesia Lumen Gentium, 21.12.1964, „Acta Apostolicae Sedis” 57 (1965), p. 5-71.

56. Sobczak A., Zastępzy charakter funkcji nadzwyczajnego szafarza komunii świętej, „Poznańskie Studia Teologiczne” 10 (2001), p. 329-337.

57. Szczot E., Prawo wiernego do Eucharystii wedtug Kodeksu Prawa Kanonicznego z 1983 roku, Lublin 2000.

58. Trevisan G., L’Eucharistia, [in:] La fuzione di santificare della Chiesa. A cura del Gruppo Italiano Docenti di Diritto Canonico, Milano 1995.

59. VII Zwyczajny Synod Biskupów z 1987 r., Lineamenta (1985), [in:] PowoŁanie i posłannictwo ludzi świeckich w świetle dokumentów kościelnych, E. Weron ed., Poznań 1989, p. 13-46. 